\title{
PENAMBAHAN GEMBILI PADA FLAKES JEWAWUT IKAN GABUS SEBAGAI ALTERNATIF MAKANAN TAMBAHAN ANAK GIZI KURANG
}

\author{
Bernadheta Gisca I.D, Arintina Rahayuni*) \\ Program Studi Ilmu Gizi Fakultas Kedokteran Universitas Diponegoro \\ Jl.Dr.Sutomo No.18, Semarang, Telp (024) 8453708, Email : gizifk@undip.ac.id
}

\begin{abstract}
Background : There has been no decline on the prevalence of malnutrition from since 2007 to 2010. Giving extra food which known as Supplementary feeding is one of the way that could be used on solving malnutrition in children. Flakes which made from barley, snakehead, and wild yam flour can be used as supplementary feeding to children with malnutririon. Expected flakes from barley, snakehead and wild yam can be an alternative of supplementary feeding for malnourished children

Objective : to analyze the effect of wild yam flour addition to the protein content, Fe, calorie value, crispness level and the acceptance level of flakes made from barley and snakehead flour.

Method : a randomized experimental design using 3 additions of wild yam flour (5\%,10\%,15\%) and one control. Statistical analysis of protein content, Fe, value and level of crispness calories tested with one Way ANOVA test, while the level of acceptance of the results of data analysis using the Friedman

Result : different percentage of wild yam flour addition has a significant effect of increasing protein content and Fe content, but does not affect the caloric value and the crispness level of the flakes. The addition of wild yam flour show a significant effect on the acceptance level of color and texture, but does not significantly affect the flavor and aroma of the flakes.

Conclusion : flakes with 10\% addition of wild yam is recomended based on protein content, Fe, caloric value, the level of crispness, and the acceptance level of the flakes.

Keyword : wild yam flour; flakes; protein content; Fe content; caloric value; crispness
\end{abstract}

\section{ABSTRAK}

Latar belakang : Angka prevalensi gizi kurang, dari tahun 2007 sampai 2010 tidak mengalami penurunan. Salah satu upaya untuk mengatasi masalah pada anak gizi kurang adalah dengan pemberian makanan tambahan (PMT). Salah satu jenis makanan yang dapat dijadikan makanan tambahan anak gizi kurang adalah flakes dengan bahan jewawut, ikan gabus, dan gembili.

Tujuan : Menganalisis pengaruh penambahan tepung gembili terhadap kadar protein, Fe, nilai Kalori, tingkat kerenyahan dan tingkat penerimaan flakes jewawut ikan gabus.

Metode : Penelitian merupakan penelitian eksperimental dengan rancangan acak lengkap menggunakan 3 penambahan tepung gembili 5\%, 10\%, 15\% dan satu kontrol. Analisis statistik dari kadar protein, Fe, nilai Kalori dan tingkat kerenyahan diuji dengan one Way Anova sedangkan analisis data hasil tingkat penerimaan diuji menggunakan Friedman

Hasil : Perbedaan persentase penambahan tepung gembili secara bermakna berpengaruh terhadap peningkatan kadar protein dan kadar Fe, tetapi tidak berpengaruh terhadap nilai kalori dan tingkat kerenyahan flakes. Penambahan tepung gembili berpengaruh nyata terhadap tingkat penerimaan warna dan teksture, tetapi tidak berpengaruh nyata terhadap rasa dan aroma flakes.

Simpulan : Berdasarkan kadar protein, Fe, nilai kalori, tingkat kerenyahan,dan tingkat penerimaan flakes yang direkomendasikan adalah flakes dengan penambahan tepung gembili $10 \%$.

Kata kunci : Tepung gembili; flakes; kadar protein; kadar Fe; nilai Kalori; tingkat kerenyahan.

\section{PENDAHULUAN}

Masa anak - anak merupakan periode yang penting dalam daur hidup manusia. Zat gizi yang optimal diperlukan anak - anak untuk mencapai pertumbuhan dan perkembangan yang optimal pula. Asupan zat gizi kurang, akan menyebabkan gangguan perkembangan dan pertumbuhan anak sehingga menyebabkan masalah gizi pada anak salah satunya kurang gizi. Masalah kurang gizi pada anak sudah terjadi sejak lama dan belum dapat terselesaikan. Menurut data dari Riskesdas 2010 diketahui bahwa secara nasional sudah terjadi penurunan prevalensi kurang gizi pada balita dari 18,4 \% tahun 2007 menjadi 17,9 \% tahun 2010. Penurunan tersebut terjadi pada prevalensi gizi buruk yaitu dari 5,4\% tahun 2007 menjadi 4,9\% tahun 2010, namun pada prevalensi gizi kurang tidak mengalami penurunan. ${ }^{1}$

Gizi kurang pada anak juga dapat disebabkan karena infeksi dan sebaliknya pada 
anak gizi kurang lebih rentan terhadap infeksi karena terjadinya penurunan kekebalan tubuh dalam melawan patogen. Patogen dalam tubuh dapat menyebabkan terjadinya penurunan absorpsi dan kehilangan zat gizi yang dibutuhkan tubuh. ${ }^{2}$ Penelitian sebelumnya ditemukan bahwa pada anak kurang gizi energi - protein sering diikuti dengan beberapa kekurangan zat gizi mikro seperti zat besi. ${ }^{3}$ Hal ini berkaitan, karena protein dibutuhkan tubuh untuk membantu absorpsi zat besi.

Salah satu upaya yang dapat dilakukan untuk mengatasi masalah pada anak gizi kurang adalah dengan pemberian makanan tambahan (PMT) pada anak. Syarat makanan tambahan bagi anak gizi kurang diantaranya adalah minimal mengandung energi $400 \mathrm{kkal}$, protein $15 \mathrm{~g}$, dan zat besi $8 \mathrm{mg}$ per $100 \mathrm{~g}$ produk serta diberikan dalam bentuk pangan lokal berupa kudapan. ${ }^{4}$ Makanan tambahan pada anak juga dapat diberikan sumber prebiotik untuk meningkatkan sistem kekebalan tubuh pada anak. ${ }^{5}$

Flakes adalah salah satu dari produk sereal sarapan yang banyak disukai oleh masyarakat. Menurut penelitian yang pernah dilakukan jenis sereal sarapan yang paling banyak dikonsumsi / disukai oleh konsumen adalah produk berupa minuman sarapan, produk ekstrusi dan flakes. ${ }^{6}$ Flakes selain digunakan sebagai sereal sarapan dapat juga digunakan sebagai makanan tambahan bagi balita karena lebih praktis dapat dimakan kapan saja, dan dapat digunakan sebagai kudapan. Flakes dapat dibuat dari berbagai macam bahan makanan yang mengandung karbohidrat dan dapat ditambahkan bahan makanan sumber zat gizi lain untuk memenuhi kebutuhan gizi. Salah satu bahan makanan sumber energi dan protein adalah jewawut dan juga ikan gabus.

Jewawut adalah salah satu bahan sumber karbohidrat yang dapat menggantikan nasi. Jewawut banyak tumbuh di Indonesia, namun pemanfaatannya masih belum banyak dan kebanyakan hanya dijadikan sebagai pakan burung. Kandungan gizi jewawut tidak kalah dengan kandungan gizi pada beras. Pada $100 \mathrm{~g}$ jewawut jenis Pearl millet mengandung 78,9 g karbohidrat, $12,8 \mathrm{~g}$ protein dan $5,6 \mathrm{~g}$ lemak sedangkan pada beras mengandung 76,0 g karbohidrat, 7,9 g protein dan 2,7 g lemak. Kandungan zat gizi lain pada jewawut adalah kandungan zat besi yang cukup yaitu $7,8 \mathrm{mg}$ per $100 \mathrm{~g}$ biji jewawut. Jewawut jenis Pearl millet dapat menyumbang energi sebesar 363 Kalori untuk setiap $100 \mathrm{~g}$, namun sebagai makanan tambahan bagi anak gizi kurang jewawut tidak mencukupi kandungan protein dan karbohidrat sehingga perlu ditambahkan bahan makanan yang mempunyai kandungan protein yang tinggi dan mudah dicerna juga sumber karbohidrat . Sumber protein yang mudah dicerna adalah sumber protein dari hewani, sedangkan sumber karbohidrat adalah gembili.

Ikan gabus adalah salah satu sumber protein dari hewani yang mudah didapatkan. Protein yang terdapat pada ikan gabus lebih tinggi daripada protein pada ikan lain. Pada $100 \mathrm{~g}$ ikan gabus mengandung protein sebesar 25,2 g dan juga mengandung asam amino yang lengkap yang dibutuhkan bagi anak gizi kurang. Daging pada ikan gabus mengandung asam - asam lemak tak jenuh dengan kadar kolesterol yang sangat rendah dan mengandung sejumlah mineral dan vitamin yang dibutuhkan tubuh. Ikan gabus mengandung zat besi heme yang mudah diserap oleh tubuh. Pada $100 \mathrm{~g}$ ikan gabus mengandung $0,9 \mathrm{mg}$ zat besi, namun jumlah tersebut tidak mencukupi sesuai dengan standar pemberian makanan tambahan yaitu $8 \mathrm{mg}$ per $100 \mathrm{~g}$ produk.

Gembili adalah salah satu jenis umbi umbian dan merupakan sumber karbohidrat. Gembili dimanfaatkan penduduk Indonesia sebagai pengganti nasi dan diolah dengan cara direbus ataupun digoreng. Gembili juga dapat diolah menjadi tepung sebagai campuran dalam pembuatan berbagai makanan.Gembili $100 \mathrm{~g}$ mengandung 31,3 g karbohidrat, 1,1 g protein, dan 0,2 lemak dan dapat menyumbang energi sebesar 131 Kalori. Gembili juga mengandung komponen yang sangat penting bagi kesehatan yaitu inulin. Kadar inulin yang terdapat pada gembili adalah sebesar 14,629 \%.7 Kadar ini lebih tinggi daripada kadar inulin dari beberapa jenis umbi yang lain. Inulin adalah salah satu jenis serat pangan yang tidak dapat dicerna dan berfungsi sebagai prebiotik yang dapat menstimulasi secara selektif pertumbuhan dan aktivitas bakteri yang menguntungkan di saluran pencernaan. Inulin juga dapat menstimulasi sistem kekebalan di dalam tubuh. Fungsi lain dari inulin adalah dapat membantu penyerapan beberapa zat gizi seperti Fe, $\mathrm{Cu}, \mathrm{Zn}, \mathrm{Ca}{ }^{8}$

Berdasarkan uraian diatas maka diharapkan flakes dari bahan tepung jewawut dan ikan gabus yang ditambah tepung gembili dapat dijadikan sebagai salah satu alternatif pilihan makanan tambahan bagi anak gizi kurang 


\section{METODE}

Penelitian yang dilakukan ditinjau dari segi keilmuan dalam bidang ilmu Food Production, yang dilaksanakan mulai bulan Juni hingga Agustus 2013 di Laboratorium Gizi Universitas Muhammadiyah Semarang, Laboratorium Ilmu Pangan Universitas Katolik Soegijapranata Semarang dan juga Laboratorium Ilmu Nutrisi dan Pakan Fakultas Peternakan dan Pertanian Universitas Diponegoro Semarang.

Penelitian ini merupakan penelitian eksperimental dengan rancangan acak lengkap menggunakan 3 penambahan tepung gembili yaitu $5 \%, 10 \% 15 \%$ dan satu kontrol. Formulasi flakes dipilih 5\%, 10\% dan 15\% karena penambahan tepung gembili yang melebihi $15 \%$ akan menyebabkan rasa flakes semakin pahit. Pemilihan formulasi kontrol diperoleh dari penelitian pendahuluan yaitu formula tepung jewawut dan tepung ikan gabus F1 (75 \%, 25\%), F2 (70\%, $30 \%)$, F3 $(65 \%, 35 \%)$ dan F4 $(60 \%, 40 \%)$. Berdasarkan hasil penelitian pendahuluan ini diketahui bahwa flakes yang paling disukai adalah flakes dengan formula tepung jewawut : tepung ikan gabus adalah 70\%: $30 \%$ (F2), sehingga hasil tersebut digunakan sebagai kontrol. Setiap perlakuan dilakukan tiga kali ulangan dan dilakukan pengukuran secara duplo, sedangkan untuk tingkat penerimaan dilakukan satu kali tanpa pengulangan.

Bahan baku yang digunakan adalah tepung jewawut, tepung ikan gabus, tepung gembili, gula halus, garam, telur ayam, margarin dan air. Tepung jewawut dibuat dari jewawut yang telah disosoh dan dihaluskan dengan ukuran 80 mesh. Proses pembuatan tepung gembili dilakukan dengan proses kering yang diawali dengan pencucian dan pengupasan umbi segar yang kemudian diiris. Setelah diiris kemudian dilakukan perendaman dengan air selama 2 hari tepung, kemudian dikeringkan dan dihaluskan dan diayak dengan ukuran 80 mesh. Perendaman selama 2 hari dilakukan untuk menghilangkan lendir dari gembili dan untuk melunakkan gembili sehingga lebih mudah dalam proses pembuatan tepung. Proses pembuatan tepung ikan gabus dilakukan dengan membersihkan bagian jerohan ikan dan juga ingsang hingga bersih kemudian dicuci. Setelah dicuci direndam dengan air perasan jeruk nipis untuk menghilangkan bau amis pada ikan gabus selama $\pm 1 \mathrm{jam}$. Setelah direndam kemudian dilakukan pengukusan dengan tekanan tinggi/presto selama 30 menit dan kemudian dikeringkan selama 1 hari, dihaluskan dan diayak dengan ukuran 80 mesh.

Flakes dibuat dengan cara mencampur semua bahan baku seperti tepung jewawut, tepung ikan gabus, telur ayam, gula halus, garam, air, margarin dan dengan atau tanpa penambahan tepung gembili yang dilakukan melalui proses pencampuran, homogenisasi, dan pemanggangan.

Data yang dikumpulkan meliputi kadar protein, kadar Fe, nilai kalori, tingkat kerenyahan, dan tingkat penerimaan flakes dengan penambahan tepung gembili. Kadar protein diukur dengan metode mikro Kjedhal, ${ }^{9}$ kadar Fe diukur dengan metode AAS, ${ }^{10}$ nilai kalori diukur dengan Bom Kalorimeter, tingkat kerenyahan diukur dengan teksture analyser, dan tingkat penerimaan menggunakan uji hedonik meliputi warna, rasa, tekstur, dan aroma ${ }^{11}$ yang diuji oleh 20 orang panelis agak terlatih yaitu mahasiswa Program Studi Ilmu Gizi Universitas Diponegoro dengan 5 skala penilaian yaitu $5=$ sangat suka, $4=$ suka, $3=$ netral, $2=$ tidak suka, $1=$ sangat tidak suka.

Pengaruh penambahan tepung gembili terhadap kadar protein, Fe, nilai Kalori, dan tingkat kerenyahan diuji menggunakan one way Anova dilanjutkan dengan uji LSD (Least Significance Different) pada derajat kepercayaan 95\%. Data hasil uji tingkat penerimaan dianalisis dengan uji Friedman dilanjutkan uji Wilcoxon menggunakan program komputer untuk mengetahui beda nyata antar perlakuan pada derajat kepercayaan $95 \%$.

\section{HASIL}

\section{Kadar Protein}

Hasil analisis protein pada flakes dengan penambahan tepung gembili dapat dilihat di tabel 1 berikut.

Tabel 1. Rerata kadar protein flakes dengan penambahan tepung gembili

\begin{tabular}{ll}
\hline Jenis perlakuan & Rerata $(\%)$ \\
\hline Kontrol & $26.96 \pm 1.308^{\mathrm{d}}$ \\
Penambahan 5\% & $32.27 \pm 1.241^{\mathrm{c}}$ \\
Penambahan 10\% & $38.61 \pm 1.282^{\mathrm{b}}$ \\
Penambahan 15\% & $45.99 \pm 1.527^{\mathrm{a}}$ \\
\hline & $\mathrm{p}=0.000$
\end{tabular}

Keterangan : angka yang diikuti dengan huruf superscipt berbeda (a,b,c,d) menunjukan beda nyata. 
Hasil analisis kadar protein menunjukkan bahwa kadar tertinggi terdapat pada flakes dengan penambahan tepung gembili $15 \%$ yaitu $45.99 \mathrm{~g}$, sedangkan nilai terendah terdapat pada flakes kontrol yaitu $26.96 \mathrm{~g}$. Hasil analisis menggunakan one way Anova CI $95 \%$ menunjukkan bahwa penambahan tepung gembili berpengaruh terhadap peningkatan kadar protein pada Flakes. Uji lanjut menggunakan LSD (Least Significiance Different) menunjukkan bahwa flakes kontrol memiliki perbedaan bermakna dengan flakes penambahan tepung gembili $5 \%, 10 \%$, dan $15 \%$. Semakin tinggi penambahan tepung gembili maka kadar protein semakin meningkat.

\section{Kadar Fe}

Hasil analisis kadar Fe dapat dilihat pada tabel 2 berikut.

Tabel 2. Rerata kadar Fe pada flakes dengan penambahan tepung gembili

\begin{tabular}{ll}
\hline Jenis perlakuan & Rerata $(\mathrm{mg} / 100 \mathrm{~g})$ \\
\hline Kontrol & $9.47 \pm 1.010^{\mathrm{d}}$ \\
Penambahan 5\% & $15.09 \pm 0.963^{\mathrm{c}}$ \\
Penambahan 10\% & $26.16 \pm 0.948^{\mathrm{b}}$ \\
Penambahan 15\% & $41.72 \pm 1.807^{\mathrm{a}}$ \\
\hline & $\mathrm{p}=0.000$ \\
\hline
\end{tabular}

Keterangan : angka yang diikuti dengan huruf superscipt berbeda (a,b,c,d) menunjukkan beda nyata.

Hasil analisis kadar $\mathrm{Fe}$ menunjukkan bahwa kadar tertinggi terdapat pada flakes dengan penambahan tepung gembili $15 \%$ yaitu $41.72 \mathrm{mg}$, sedangkan kadar Fe terendah terdapat pada flakes kontrol yaitu $9.47 \mathrm{mg}$. Hasil analisis menggunakan one way Anova CI 95\% menunjukkan bahwa penambahan tepung gembili berpengaruh terhadap peningkatan kadar $\mathrm{Fe}$ pada flakes. Uji lanjut menggunakan LSD (Least Significiance Different) menunjukkan bahwa flakes kontrol memiliki perbedaan bermakna dengan flakes penambahan tepung gembili $5 \%, 10 \%$, dan $15 \%$.

\section{Nilai Kalori}

Hasil analisis nilai Kalori dapat dilihat pada tabel 3 berikut.

Tabel 3. Rerata nilai Kalori pada flakes dengan penambahan tepung gembili

\begin{tabular}{ll}
\hline Jenis perlakuan & Rerata (kkal) \\
\hline Kontrol & $512.50 \pm 26.11$ \\
Penambahan 5\% & $516.80 \pm 20.82$ \\
Penambahan 10\% & $474.66 \pm 4.78$ \\
Penambahan 15\% & $493.67 \pm 9.27$ \\
\hline & $\mathrm{p}=0.630$ \\
\hline
\end{tabular}

Hasil analisis nilai Kalori menunjukkan bahwa nilai kalori teringgi terdapat pada flakes dengan penambahan tepung gembili $5 \%$ dengan nilai rerata 516.80 kkal sedangkan nilai kalori terendah terdapat pada flakes dengan penambahan tepung gembili $10 \%$ dengan nilai rerata 474.66 kkal. Hasil analisis menggunakan one way Anova menujukkan bahwa tidak ada pengaruh penambahan tepung gembili terhadap nilai kalori flakes.

\section{Kerenyahan}

Hasil analisis tingkat kerenyahan dapat dilihat pada tabel 4 berikut.

Tabel 4. Rerata tingkat kerenyahan pada flakes dengan penambahan tepung gembili

\begin{tabular}{ll}
\hline Jenis perlakuan & Rerata $(\mathrm{gf})$ \\
\hline Kontrol & $512.39 \pm 39.32$ \\
Penambahan 5\% & $439.55 \pm 30.30$ \\
Penambahan 10\% & $458.12 \pm 18.06$ \\
Penambahan 15\% & $482.02 \pm 19.54$ \\
\hline & $\mathrm{p}=0.060$ \\
\hline
\end{tabular}


Hasil analisis tingkat kerenyahan menujukkan bahwa flakes dengan tingkat kerenyahan yang tinggi adalah flakes dengan penambahan $5 \%$, dengan nilai rerata 439.55 gf, sedangkan flakes dengan kerenyahan yang rendah adalah flakes kontrol dengan nilai rerata 512.39 gf. Nilai kerenyahan diukur dengan Texture Analyser, hasil uji terhadap tingkat kerenyahan menujukkan bahawa semakin tinggi nilai maka menunjukkan bahwa flakes semakin keras, namun sebaliknya semakin rendah nilai maka menunjukkan bahwa flakes semakin renyah. Hasil uji dengan One way Anova menunjukkan bahwa tidak ada pengaruh penambahan tepung gembili terhadap tingkat kerenyahan flakes.

\section{Tingkat penerimaan}

Tingkat penerimaan flakes diperoleh melalui uji hedonik yang meliputi warna, aroma, tekstur, dan rasa. Hasil uji tingkat penerimaan terhadap flakes dapat dilihat pada tabel 5 berikut.

Tabel 5. Hasil analisis tingkat penerimaan Flakes

\begin{tabular}{ccccccccc}
\hline \multirow{2}{*}{ Perlakuan } & \multicolumn{2}{c}{ Warna } & \multicolumn{2}{c}{ Aroma } & \multicolumn{2}{c}{ Tekstur } & \multicolumn{2}{c}{ Rasa } \\
\cline { 2 - 8 } & Rerata & Ket & Rerata & Ket & Rerata & Ket & Rerata & Ket \\
\hline $\begin{array}{c}\text { Kontrol } \\
\text { Penambahan } \\
5 \%\end{array}$ & $3.6 \pm 0.883^{\text {ac }}$ & Suka & $3.25 \pm 1.019$ & Netral & $3.2 \pm 0.952^{\mathrm{b}}$ & Netral & $3.4 \pm 0.933$ & Netral \\
$\begin{array}{c}5 \% 0.853^{\text {ab }} \\
\text { Penambahan }\end{array}$ & Netral & $3.05 \pm 0.826$ & Netral & $3.4 \pm 0.681^{\mathrm{b}}$ & Netral & $3.2 \pm 0.767$ & Netral \\
$\begin{array}{c}10 \% \\
\begin{array}{c}\text { Penambahan } \\
15 \%\end{array}\end{array}$ & $3.6 \pm 0.826^{\mathrm{c}}$ & Suka & $3.35 \pm 0.746$ & Netral & $4.1 \pm 0.605^{\mathrm{a}}$ & Suka & $3.7 \pm 1.137$ & Suka \\
\hline & $2.8 \pm 0.767^{\mathrm{b}}$ & Netral & $3.1 \pm 0.852$ & Netral & $3.2 \pm 1.268^{\mathrm{b}}$ & Netral & $3.3 \pm 0.786$ & Netral \\
\hline
\end{tabular}

Keterangan : angka yang diikuti dengan huruf superscipt berbeda $(\mathrm{a}, \mathrm{b}, \mathrm{c})$ menunjukkan beda nyata.

Hasil uji kesukaan terhadap warna menunjukkan bahwa kesukaan tertinggi pada flakes tanpa penambahan tepung gembili yaitu 3.60 (suka), sedangkan flakes dengan kesukaan warna terendah adalah flakes dengan penambahan tepung gembili $15 \%$ yaitu 2.80 (netral).

Hasil uji kesukaan terhadap aroma flakes dengan penambahan tepung gembili menunjukkan bahwa semua perlakuan memiliki kategori netral yang artinya aroma pada flakes masih dapat diterima oleh panelis. Tingkat kesukaan pada aroma dengan nilai tertinggi yaitu pada penambahan $10 \%$ tepung gembili yaitu 3.35 (netral), sedangkan tingkat kesukaan terendah yaitu pada penambahan 5\% tapung gembili yaitu 3.05 (netral).

Hasil uji kesukaan terhadap tektur flakes dengan penambahan tepung gembili menunjukkan nilai tertinggi kesukaan terhadap tekstur adalah pada penambahan tepung gembili $10 \%$ yaitu 4.1 (suka), sedangkan tingkat kesukaan terhadap tektur dengan nilia terendah yaitu pada penambahan $15 \%$ yaitu 3.2 (netral).

Hasil uji kesukaan terhadap rasa flakes menunjukkan bahwa flakes dengan tingkat kesukaan tertinggi yaitu pada flakes dengan penambahan $10 \%$ tepung gembili yaitu 3.7 (suka), sedangkan flakes dengan tingkat kesukaan terendah yaitu pada penambahan $5 \%$ yaitu 3.2 (netral).

\section{PEMBAHASAN}

\section{Kadar Protein}

Protein merupakan zat gizi yang penting khususnya bagi anak kurang gizi. Protein dibutuhkan untuk pertumbuhan dan perkembangan bagi anak. Asam amino yang membentuk protein merupakan bahan pembentuk sebagian besar koenzim, hormon, asam nukleat dan molekul molekul esensial lainnya.Flakes tepung jewawut dan ikan gabus dengan penambahan tepung gembili menunjukkan bahwa terdapat perbedaan yang nyata pada setiap perlakuan. Flakes kontrol mempunyai kadar protein yang lebih rendah daripada flakes dengan penambahan tepung gembili. Kadar protein pada masing - masing perlakuan melebihi standar formula tambahan bagi anak gizi kurang yaitu $15-20 \mathrm{~g} / 100 \mathrm{~g}$ bahan. Kadar protein pada flakes berkisar antara $26.69-$ $45.99 \mathrm{~g}$, sehingga protein dalam flakes dapat menyumbang kebutuhan protein sebesar $133.45 \%$ $229.95 \%$ dari standar bahan makanan tambahan bagi anak gizi kurang.

Peningkatan kadar protein pada setiap perlakuan terjadi karena bahan yang digunakan dalam pembuatan flakes mempunyai kandungan protein yang tinggi. Kandungan protein pada $100 \mathrm{~g}$ ikan gabus kering adalah $58 \mathrm{~g}$ dan jewawut 11.8 g. ${ }^{12}$ Selain bahan tersebut dalam pembuatan flakes juga ditambahkan bahan telur yang mengandung 
$6.3 \mathrm{~g}$ protein. $^{13}$ Telur ditambahkan dalam pembuatan flakes bertujuan untuk pelembut atau pengempuk dan pengembang. Penambahan tepung gembili berpengaruh terhadap peningkatan kadar protein dalam flakes. Kandungan protein pada tepung gembili adalah $6.11 \mathrm{~g} .{ }^{14}$

Kandungan protein yang melebihi kecukupan tidak akan menimbulkan risiko keracunan. Protein yang dikonsumsi seseorang dalam tubuh akan diubah menjadi energi, glukosa dan lemak. Protein yang disimpan akan diubah menjadi glukosa sehingga berfungsi sebagai penstabil kadar gula dalam darah dan menyediakan keperluan glukosa oleh otak. Kelebihan asupan protein pada anak dapat memperberat kerja ginjal karena ginjal bekerja menyaring produk - produk sisa dari metabolisme tubuh seperti urea dari metabolisme protein.

\section{Kadar zat Besi (Fe)}

Zat besi adalah salah satu zat gizi yang dibutuhkan bagi anak gizi kurang. Zat besi yang terdapat dalam enzim - enzim bertanggung jawab mengangkut elektron dari sitokrom, mengaktifkan oksigen (oksidase dan oksigenase) serta mengangkut oksigen melalui ikatan hemoglobin dan mioglobin. Zat besi juga mempengaruhi kemampuan belajar dan sistem kekebalan tubuh. ${ }^{15}$

Produk flakes ini diketahui bahwa ada pengaruh penambahan tepung gembili terhadap peningkatan kadar $\mathrm{Fe}$ pada masing - masing perlakuan. Flakes kontrol memiliki kadar zat besi yang lebih rendah dari pada flakes dengan penambahan tepung gembili. Hal ini disebabkan karena pada $100 \mathrm{~g}$ umbi gembili mengandung 0.6 $\mathrm{mg}$ zat besi. Bahan pembuat flakes mempunyai kandungan $\mathrm{Fe}$ yang tinggi. Jewawut dan ikan gabus kering berturut - turut mempunyai kandungan Fe $7.12 \mathrm{mg}$ dan $0.7 \mathrm{mg}$ Kadar zat besi pada flakes kontrol adalah $9.47 \mathrm{mg}$, sehingga sesuai dengan standar bahan makanan tambahan bagi anak gizi kurang yaitu $12 \mathrm{mg}$.

Kadar zat besi pada flakes dengan penambahan tepung gembili $5 \%, 10 \%$, dan $15 \%$ berturut - turut melebihi standar bahan makanan bagi anak gizi kurang yaitu $15.09 \mathrm{mg}, 26.16 \mathrm{mg}$, dan $41.72 \mathrm{mg}$. Keracunan Fe dari makanan jarang dilaporkan, karena keracunan biasanya disebabkan karena suplemen besi dalam jangka waktu yang lama dan juga karena transfusi darah. Keracunan $\mathrm{Fe}$ karena penggunaan suplemen dosis tinggi dalam jangka waktu yang lama dapat menyebabkan muntah, diare, denyut jantung meningkat, sakit kepala, dan pingsan. Keracunan $\mathrm{Fe}$ dosis tinggi biasa terjadi karena konsumsi $\mathrm{Fe}$ oral ferosulfat dosis $40-1600 \mathrm{mg} / \mathrm{kg}$ (rata - rata konsumsi $900 \mathrm{mg}$ ).

\section{Nilai Kalori}

Nilai kalori adalah satuan unit yang digunakan untuk mengukur nilai energi. Besarnya kandungan energi dari suatu produk makanan tergantung dari kadar lemak, protein, dan karbohidrat. Kadar protein dan karbohidrat memberikan nilai energi sebesar 4 kkal, sedangkan kadar lemak memberikan nilai energi sebesar 9 kkal. Jewawut 100 g mengandung lemak sebesar $11.12 \mathrm{~g}$, karbohidrat $67.0 \mathrm{~g}$, dan protein 11.12 g. Kandungan $100 \mathrm{~g}$ ikan gabus kering mengandung lemak $4.0 \mathrm{~g}$ dan protein $512.0 \mathrm{~g}$, sedangkan pada $100 \mathrm{~g}$ tepung gembili mengandung lemak 0.129 g, dan karbohidrat 42.16 g. Kandungan gizi pada telur adalah $6.3 \mathrm{~g}$ protein, 0.6 g karbohidrat, dan $5 \mathrm{~g}$ lemak. Uji statistik flakes diketahui bahwa tidak ada pengaruh penambahan tepung gembili terhadap nilai Kalori. Nilai kalori pada masing - masing perlakuan tidak berbeda dan masih memenuhi syarat bahan makanan tambahan bagi anak gizi kurang yaitu $400 \mathrm{kkal} / 100 \mathrm{~g}$ bahan. Nilai Kalori pada masing - masing perlakuan flakes berkisar antara 474.66 - $516.120 \mathrm{kkal}$. Hal ini disebabkan karena tepung gembili yang ditambahkan hanya sedikit sehingga tidak mempengaruhi nilai kalori.

\section{Tingkat kerenyahan}

Kerenyahan merupakan sifat fisik yang penting dalam suatu produk makanan pada khususnya flakes. Kerenyahan pada makanan ditentukan oleh kelembaban dan kandungan lemak, jenis dan jumlah karbohidrat struktural (selulosa, pati dan pektin), serta kandungan protein. Perbedaan kandungan protein akan mempengaruhi kerenyahan karena adanya ikatan - ikatan antara molekul protein akan membentuk suatu matriks. Kandungan lemak juga dapat mempengaruhi sifat renyah dari produk. Lemak akan berikatan dengan amilosa dan amilopektin sehingga dapat menghambat pengembangan dan mengurangi sifat renyah dari produk. Perbedaan kandungan amilosa dan amilopektin dalam pati juga berpengaruh terhadap nilai kerenyahan suatu produk. Amilosa merupakan polisakarida yang linier sedangkan amilopektin polisakarida yang berupa cabang. ${ }^{16}$ Kandungan amilopektin yang tinggi akan membuat produk mudah mengembang. Sedangkan produk yang terbuat dari pati beramilosa tinggi akan lebih rapat, lebih keras dan kurang mengembang. ${ }^{16}$

Uji statistik diketahui bahwa tidak ada pengaruh penambahan tepung gembili terhadap tingkat kerenyahan flakes. Hal ini disebabkan 
karena proporsi penambahan tepung gembili yang tidak terlalu banyak sehingga tidak mempengaruhi tingkat kerenyahan flakes. Tepung gembili mengandung amilosa $9.12 \%$ dan kadar amilopektin $91.2 \% .^{14}$ Jewawut dikelompokkan dalam jenis ketan karena mengandung amilopektin yang tinggi yaitu $75 \%$ dan amilosa $25 \% .{ }^{17}$

\section{Tingkat Penerimaan}

\section{a. Warna}

Warna merupakan salah satu komponen yang penting dalam menentukkan kualitas dari penerimaan suatu makanan. Penentuan mutu suatu bahan pangan pada umumnya tergantung pada warna karena warna tampil terlebih dahulu. Warna pada flakes dipengaruhi oleh pemasakan dan juga bahan yang digunakan.

Warna pada flakes cenderung gelap dikarenakan bahan yang digunakan yaitu tepung ikan gabus dan gembili yang berwarna kecoklatan. Warna coklat pada tepung gembili disebabkan karena terjadinya reaksi pencoklatan enzimatik ketika pengolahan menjadi tepung yang disebabkan oleh aktivitas oksidase seperti fenolase atau polifenolase dan katekolase yang akan mengkatalisis reaksi oksidasi senyawa fenol menjadi keton. ${ }^{13}$ Warna flakes selain karena reaksi pencoklataan secara enzimatis juga disebabkan karena reaksi pencoklatan secara nonenzimatik yaitu reaksi Maillard selama pemanggangan. Reaksi Maillard adalah reaksi - reaksi antara karbohidrat, khususnya gula pereduksi dengan gugus amina primer. $^{16}$ Warna pada setiap perlakuan flakes cenderung sama yaitu coklat, namun masih dapat diterima oleh panelis dan digolongkan dalam kategori suka dan netral. Flakes dengan penambahan gembili 10\% lebih disukai daripada flakes dengan penambahan gembili $5 \%$ dan juga 15\%, namun sama dengan flakes kontrol . Hal ini dapat disebabkan karena penambahan $10 \%$ tepung gembili mempunyai komposisi perpaduan warna yang disukai oleh panelis.

Warna coklat pada pembuatan tepung ikan dapat dicegah dengan perendaman air jeruk nipis \pm 6 jam karena penurunan $\mathrm{pH}$ mengakibatkan warna tepung ikan menjadi lebih terang, selain itu dalam larutan jeruk nipis terdapat alpha hydroxy acid (AHA) yang berfungsi untuk memberikan efek pencerahan. ${ }^{18}$ Warna coklat akibat reaksi fenolase pada tepung gembili dapat dicegah dengan cara meminimalkan kontak dengan udara yaitu dengan cara perendaman dengan air (atau larutan garam $1 \%$ ) dan atau menginaktifkan enzim dalam proses blansir. Metode lain yang dapat dilakukan dengan proses sulfitasi yaitu dengan merendamnya dengan larutan $\mathrm{Na}-$ metabisulfit. Larutan $\mathrm{Na}-$ metabisulfit dapat mencegah reaksi antara gula pereduksi dengan asam amino. Gugus gula tidak mempunyai kesempatan untuk bereaksi dengan asam amino. $\mathrm{Na}$ - metabisulfit akan membentuk reaksi dengan gula pereduksi membentuk asam hidrosulfonat, sehingga reaksi pencoklatan dapat dicegah. ${ }^{19}$ Penggunaan sulfit dibatasi hingga 500 ppm.

\section{b. Aroma}

Aroma pada makanan banyak menentukan kualitas produk dari makanan. Aroma makanan dapat dikenali bila berbentuk uap, dan molekul molekul komponen aroma tersebut harus menyentuh silia sel olfaktori. Aroma pada flakes tepung jewawut dan ikan gabus dengan penambahan tepung gembili cenderung beraroma amis. Aroma amis pada flakes disebabkan oleh tepung ikan gabus yang digunakan. Aroma amis pada ikan disebabkan oleh komponen nitrogen yaitu guanidin, trimetil amin oksida (TMAO), dan turunan imidazol. ${ }^{18}$ Aroma pada flakes tidak berpengaruh terhadap tingkat penerimaan oleh panelis. Flakes mempunyai tingkat penerimaan yang sama terhadap aroma. Aroma amis pada ikan dapat dikurangi dengan perendaman pada air jerik nipis selama \pm 6 jam, hal ini disebabkan karena air jeruk nipis mengandung minyak atsiri Limonen yang dapat menghilangkan bau amis pada ikan tersebut. ${ }^{18}$

\section{c. Tekstur}

Tekstur pada makanan adalah hal yang berkaitan dengan struktur makanan yang dirasakan di mulut. Tekstur juga mempengaruhi kualitas dari produk makanan. Hasil uji statistik diketahui bahwa ada pengaruh penambahan tepung gembili terhadap tingkat penerimaan tekstur flakes. Penambahan tepung gembili $15 \%$ mempunyai tingkat penerimaan tekstur netral. Hal ini dapat disebabkan karena kandungan serat dalam gembili yang menyebabkan tekstur flakes menjadi kasar ${ }^{19}$, selain itu semakin tinggi penambahan tepung gembili maka kandungan amilosa dan suhu gelatinisasi semakin tinggi yang menyebabkan flakes mempunyai tekstur yang keras. Flakes kontrol mempunyai nilai yang tidak berbeda dengan flakes dengan penambahan tepung gembili $5 \%$. Tekstur flakes dengan penambahan gembili $10 \%$ paling disukai oleh panelis, hal ini disebabkan karena komposisi tepung gembili yang tidak terlalu banyak sehingga mampu menutupi rasa kasar dari tepung jewawut namun tidak terlalu keras karena sedikit kandungan seratnya. 


\section{d. Rasa}

Rasa adalah salah satu aspek yang penting dari suatu produk makanan. Rasa juga dapat menentukkan apakah produk makanan tersebut dapat diterima atau tidak oleh konsumen. Rasa makanan dapat dikenali oleh papila yang terdapat pada lidah. Rasa pada makanan terdiri dari rasa asin, manis, pahit, asam. Rasa pada makanan dipengaruhi oleh beberapa faktor yaitu senyawa kimia, suhu, konsentrasi dan interaksi dengan komponen rasa lain.Uji statistik flakes diketahui bahwa tidak ada pengaruh penambahan tepung gembili terhadap tingkat penerimaan rasa. Tingkat penerimaan tergolong netral dan suka. Rasa pada flakes tergolong manis karena adanya komposisi gula dalam pembuatan flakes, namun mempunyai after taste pahit sehingga tidak begitu disukai panelis. Tingkat penerimaan yang paling disukai oleh panelis adalah pada flakes dengan penambahan tepung gembili 10\%, hal ini disebabkan karena rasa pada flakes tidak terlalu amis dan tidak begitu pahit. Semakin tinggi penambahan tepung gembili maka akan menimbulkan after taste yang pahit. Rasa pada flakes kontrol dan flakes dengan penambahan tepung gembili 5\% mempunyai tingkat penerimaan yang sama terhadap rasa yang yaitu netral hal ini disebabkan karena pada flakes masih terasa amis, sedangkan pada penambahan tepung gembili $15 \%$ flakes mempunyai after taste yang pahit. After taste pahit pada flakes dapat disebabkan karena hidrolisis asam - asam amino yang terjadi pada reaksi Maillard pada saat pembuatan tepung gembili, ikan gabus dan pemanggangan flakes. ${ }^{16}$ Rasa pahit juga dapat disebabkan oleh senyawa kimia seperti fenolik dan alkaloid pada gembili. Alkaloid yang terkandung dalam gembili adalah alkaloid dioscorin yang larut dalam air dan hilang jika direndam dalam larutan yang mengandung air kapur. ${ }^{7}$ Rasa pahit yang disebabkan oleh senyawa kimia seperti fenolik dapat dicegah dengan perendaman pada air pada saat pembuatan tepung gembili.

\section{Sumbangan nilai gizi}

Penentuan persentase dan angka kecukupan gizi suatu produk diperlukan untuk mengetahui besarnya sumbangan produk ini akan zat gizi sehingga dapat memenuhi besarnya sumbangan produk ini akan zat gizi yang diperlukan bagi tubuh. Berdasarkan hasil uji organoleptik terhadap warna, aroma, teksture, dan rasa diketahui bahwa nilai tertinggi terdapat pada flakes dengan penambahan tepung gembili $10 \%$. Kadar Protein dan Zat besi semua perlakuan masuk dalam standar bahan makanan tambahan untuk balita gizi kurang. Nilai kalori semua perlakuan juga sesuai dengan standar bahan makanan tambahan bagi anak gizi kurang, selain itu pada tingkat kerenyahan tidak ada pengaruh penambahan tepung gembili sehingga dapat dipilih flakes dengan perlakuan manapun. Melihat dari segi uji organoleptik tingkat penerimaan tertinggi ada pada flakes dengan penambahan $10 \%$ maka dipilih formula sebagai produk yang disarankan. Flakes dengan penambahan tepung gembili $10 \%$ diketahui mempunyai nilai gizi $474.66 \mathrm{kkal}, 312.61 \mathrm{~g}$ protein, $26.16 \mathrm{mg} \mathrm{Fe}$, sehingga takaran produk per sajian adalah sebesar $125 \mathrm{~g}$ dengan sumbangan kecukupan dapat dilihat pada tabel 9 berikut.

Tabel 9. Sumbangan zat gizi flakes dengan penambahan tepung gembili $10 \%$

\begin{tabular}{lllll}
\hline Zat Gizi & $\begin{array}{l}\text { Standar bahan } \\
\text { makanan } \\
\text { tambahan anak }\end{array}$ & $\begin{array}{l}\text { Kandungan } \\
\text { 100g flakes }\end{array}$ & $\begin{array}{l}\text { Kandungan } \\
125 \text { g flakes }\end{array}$ & $\begin{array}{l}\text { Persentase } \\
\text { sumbangan } \\
(\%) 125 \mathrm{~g}\end{array}$ \\
\hline Kalori (kkal) & 400 & 474.66 & 400 & 100.00 \\
Protein $(\mathrm{g})$ & 15 & 312.61 & 32.54 & 216.93 \\
Zat besi $(\mathrm{mg})$ & 12 & 26.16 & 22.05 & 275.63 \\
\hline
\end{tabular}

Inulin adalah senyawa karbohidrat yang merupakan polimer dari unit - unit fruktosa. Inulin termasuk dalam serat makanan yang tidak mengandung kalori dan bermanfaat bagi tubuh. Inulin bersifat larut dalam air, tidak dapat dicerna oleh enzim - enzim pencernaan sehingga mencapai usus besar tanpa mengalami perubahan struktur, namun dapat mengalami fermentasi akibat aktivitas mikroflora sehingga dapat berfungsi sebagai prebiotik. Inulin telah digunakan dan ditambahkan pada formula bayi karena berpotensial sebagai prebiotik untuk memodulasi flora di sistem pencernaan dan mempengaruhi sistem imunitas. ${ }^{20}$ Manfaat lain dari inulin adalah dapat meningkatkan absorpsi dari kalsium, magnesium, fosfor, tembaga, zat besi dan zink. ${ }^{21}$ 


\section{KESIMPULAN}

1. Kadar Protein dan kadar Fe paling tinggi adalah flakes dengan penambahan tepung gembili $15 \%$.

2. Penambahan tepung gembili mempunyai pengaruh terhadap peningkatan kadar Protein dan Fe flakes.

3. Takaran jumlah sajian yang disarankan untuk flakes dengan penambahan tepung gembili $10 \%$ adalah $125 \mathrm{~g}$ per sajian.

4. Penambahan tepung gembili mempunyai pengaruh terhadap tingkat penerimaan warna dan teksture flakes.

\section{SARAN}

1. Sebagai alternatif makanan tambahan bagi anak gizi kurang maka flakes yang direkomendasikan berdasarkan hasil penelitian ini adalah flakes dengan penambahan tepung gembili $10 \%$.

2. Untuk mencegah terjadinya proses browning pada tepung ikan perlu dilakukan perendaman dengan air jeruk nipis selama 6 jam

3. Untuk mencegah reaksi browning pada tepung gembili dapat dilakukan dengan proses sulfitasi yaitu dengan merendam dengan larutan $\mathrm{Na}-$ metabisulfit.

\section{DAFTAR PUSTAKA}

1. Riset Kesehatan Dasar (RisKesDas) Tahun 2010. Badan Penelitian dan Pengembangan Kesehatan Kementerian Kesehatan RI;2010

2. Jorge R Mujico, Fatima Perez-de-Heredia, Sonia Gomez-Martinez and Ascension Marcos (2012). Malnutrition and Inflamation, Inflamation, Chronic, Diseases and Cancer - Cell and Molecular Biology, Immunology and Clinical Bases, Dr. Mahin Khatami (Ed), ISBN:978-95352-0102-4, In Tech.

3. Calder, C. Philip, Jackson A. Alan. Undernutrition, Infection and immune fuction. Nutrition Research Reviews. 2000; 13,3-29

4. FAO/WHO. Guidelines on Formulated Suplementary Food for Older Infants and Young Children. Roma : FAO/WHO;1994

5. Clara M. Kusharto, Ingrid S. Surono, Annis Catur Adi. Efikasi Pemberian Makanan Tambahan (PMT) Biskuit Fungsional Berbasis Sinbiotik dengan Prebiotik asal pangan lokal dan prebiotik pada balita gizi kurang. Institut Pertanian Bogor. Bogor. 2010

6. Nurjanah, E. Analisis Karakteristik Konsumen dan Pola Konsumsi Sereal Sarapan [Skripsi], Institut Pertanian Bogor, Bogor. 2000.

7. Yuniar, D.P. Karakteristik beberapa Umbi Uwi (Discorea spp) dan Kajian Potensi Kadar
Inulinnya. (Skripsi). Fakultas Teknologi Industri. Surabaya: Universitas Pembangunan Naional “ Veteran". 2010

8. Scholz - Ahrens, Katharina E; Schrezenmeir, Jorgen. 2007. Inulin and Oligofructose and Mineral Metabolism: The Evidence from Animal Trial. The Jurnal of Nutrition 2007; 2513 S 2523S

9. Slamet Sudarmadji, Bambang Haryono, Suhardi. Prosedur analisa untuk bahan makanan dan pertanian. Yogyakarta: Liberty. 2007

10. Harry Budiman, Fransiska Sri Herwahyu Krismastuti, Nuryatini. Penentuan Kandungan Besi dalam Contoh Makanan Menggunkan Graphite Furnance Atomic Absorption Spectrometry dalam Uji Profisiensi FNRI - DOST. Pusat Penelitian Kimia - Lembaga Ilmu Pengetahuan Indonesia. Serpong. Banten. 2000

11. Soekarto. Penilaian organoleptik untuk industri pangan dan hasil pertanian. Jakarta : Bharatara Karya Aksara. 1985.

12. Prabowo, Bimo. Kajian sifat fisikokimia tepung millet kuning dan tepung millet merah [skripsi].Fakultas Pertanian: Universitas Sebelas Maret. Surakarta. 2010.

13. Sudaryani, T. 2003. Kualitas Telur. Penebar Swadaya. Jakarta.

14. Richana, Nur, Titi Chandra Sunarti. Karakteristik Sifat Fisikokimia Tepung Umbi dan Tepung Pati dari Umbi Ganyong, Suweg, Ubi Kelapa dan Gembili. J. Pascapanen I(I) 2004:29 - 37

15. Lynch, Sean. Case Iron. Am J Clin Nutr 2011; 94 (suppl): 673S - 8S

16. Winarno. Kimia pangan dan Gizi. Jakarta : PT Gramedia Pustaka Utama; 2004.

17. Balitsereal 2004. Laporan akhir : Penelitian koleksi, karakteristik, dan konverservasi plasma nutfah serealia. Litbang Pertanian, 49 hal (Tidak dipublikasikan)

18. Maulida, Nurul. Pemanfaatan Tepung Tulang Ikan Madidihang Sebagai Suplemen dalam Pembuatan Biskuit [skripsi]. Fakultas Perikanan dan Ilmu Kelautan. Institut Pertanian Bogor. Bogor; 2005.

19. Yananta, Ane Putri. Perbaikan Proses Produksi Tepung Umbi Minor [skripsi]. Fakultas Teknologi Pertanian. Institut Pertanian Bogor. Bogor; 2003.

20. Veereman, Gigi. Pediatric Application of Inuin and Oligofructose. The Jurnal of Nutrition137:2586S 2589S, 2007.

21. Katharina E. Scholz - Ahrens, Jurgen Schrezenmeir. Inulin and Mineral Metabolism : The Evidence from Animal Trials. J. Nutr. 137 : 2513S - 2523 S , 2007. 